\title{
The letter to the Romans as Paul's legacy to theology: Reception in exposition ${ }^{1}$
}

\author{
Breytenbach, Cilliers \\ Stellenbosch University \\ breytenc@hu-berlin.de
}

\begin{abstract}
'The Romans Debate' fills not only volumes, but nowadays a bookshelf. In this paper I will neither argue in favour nor against this verdict of Bornkamm on the setting of Romans. Approaching his idea of the letter to the Romans as Paul's legacy from reception history, I want to argue that the letter to the Romans became Paul's legacy to Christian theology. In fact, it is the legacy of Paul. What I mean is that the reception of Paul's theology is intertwined with the 'Wirkungsgeschichte' of the letter to the Romans. Pauline theology had its impact through the letter to the Romans.
\end{abstract}

Key words

Romans debate; Bornkamm; Paul's legacy; letter to Romans

Dedicated to Andrie du Toit, who introduced me to Paul's letter to the Romans

In 1977 I was a second year student of theology at the University of Pretoria. I remember well how Andrie du Toit came into the class, handing out notes introducing us to Paul, very clearly written, concise notes on the vita Pauli. He then lectured on the topic, referring to his notes. There were two sessions a week during which we were introduced to Paul. For the second session Andrie du Toit asked us to prepare certain sections from the book 'Paulus' by Günther Bornkamm. ${ }^{2}$ He remarked that this was to be a discussion

1 A first draft of this paper was read at a symposium 'Reflection on Romans' in honour of Andrie B. du Toit, University of Pretoria, September 22, 2011.

2 G. Bornkamm, Paulus (Stuttgart: Kohlhammer, 1969). 
class, he was not lecturing on the topic, and we would have to discuss Bornkamm's work, not his. This procedure made a lifelong impression on me. ${ }^{3}$ By distinguishing between his lectures on Paul's life during the first session of the week and the discussion class on Bornkamm's Paul, Andrie $\mathrm{du}$ Toit demonstrated the integrity branding his academic career. Unlike others, he would never have lectured using Bornkamm's material as if it were his.

In the first part of Bornkamm's famous book there is a section on 'Der Römerbrief als Testament des Paulus'. ${ }^{4}$ I vividly remember how Andrie introduced us to Bornkamm's hypothesis why Romans had been written. Being in Corinth, Paul is on the brink of bringing the collection to Jerusalem. Afterwards he wants to go to Rome to set up his Spanish mission in the West. ${ }^{5}$ Would the followers of Jesus in Jerusalem, those around James, the brother of the Lord, accept the money that the nonJewish brothers and sisters from the Pauline congregations send to them? For Bornkamm this is the reason why Paul personally accompanied the delegation which delivered the collected money to Jerusalem. Bornkamm understood the letter from the Romans based on this situation in Paul's life. 'Sein Inhalt kreist genau um die Fragen und Intentionen der Theologie des Apostels, für die er bald danach sich in Jerusalem verantworten und einsetzen mußte und die zugleich das Fundament seiner künftigen Mission unter den Heiden bleiben und werden sollte.' ${ }^{6}$ The letter to the Romans isn't a theological treatise without a specific setting. All the other letters of Paul have their own situations, so does the letter to the Romans. In this letter Paul sums up his previous theological insights and applies them to the challenging situation to defend his gospel before the Jewish leaders of the congregation of God in Jerusalem and to find support for his ongoing

3 Of course we had other teachers, too, - no names - some who asked us to bring the book they wrote and to discuss that in class, some who asked us to bring the book that someone else wrote and then told us which sections to underline and to study, complementing it with additional notes and even someone who rehearsed someone else's book and then presented it as if it were his own work.

4 Cf. also G. Bornkamm, 'Der Römerbrief als Testament des Paulus', in Geschichte und Glaube: Zweiter Teil (vol. 4 of Gesammelte Aufsätze; ed. G. Bornkamm; BEvT 53; München: Chr. Kaiser, 1971), pp. 120-139.

5 Bornkamm, Paulus, p. 105.

6 Bornkamm, Paulus, p. 108. 
mission to the Gentiles amongst the beloved of God in Rome. 'Historisch darf man den Römerbrief das Testament des Paulus nennen.'7

'The Romans Debate' fills not only volumes, but nowadays a bookshelf. ${ }^{8}$ In this paper I will neither argue in favour nor against this verdict of Bornkamm on the setting of Romans. Approaching his idea of the letter to the Romans as Paul's legacy from reception history, I want to argue that the letter to the Romans became Paul's legacy to Christian theology. In fact, it is the legacy of Paul. What I mean is that the reception of Paul's theology is intertwined with the 'Wirkungsgeschichte' of the letter to the Romans. ${ }^{9}$ Pauline theology had its impact through the letter to the Romans.

Many of us who gather here today are part of the 'Wirkungsgeschichte' of Paul's letter. First and foremost Andrie du Toit, for the greater part of his career was dedicated to the study of Romans. ${ }^{10}$ With the hallmark of his work, exegetical precision, he thought us to focus on the text of Romans, to get to the message. This of course is best achieved in the genre of the commentary. It has always been those having to do exegesis on Romans who felt the impact of the letter most. In the following I shall attempt to characterize major commentaries on Romans during the course of the history of Christian theology. ${ }^{11}$ As an illustration, I will thereby concentrate

7 Bornkamm, Paulus, p. 111.

8 Cf. K. P. Donfried, ed., The Romans Debate (rev. and expanded ed.; Peabody, Mass.: Hendrickson, 1991); J. C. Miller, 'The Romans Debate 1991-2001,' CurBS 9 (2001): pp. 306-349.

9 Cf. also J. P. Greenman and T. Larsen, eds., Reading Romans through the Centuries: From the Early Church to Karl Barth (Grand Rapids, Mich.: Brazos, 2005); W. Wischmeyer, 'Die Rezeption des Paulus in der Geschichte der Kirche,' in Paulus: Leben - Umwelt - Werk - Briefe (ed. O. Wischmeyer; Tübingen: Francke, 2006), pp. 358-368; C. Breytenbach, ed., Der Römerbrief als Vermächtnis an die Kirche: Rezeptionsgeschichten aus zwei Jahrtausenden (Neukircheni-Vluyn: Neukirchener Verlag, 2012).

10 A. B. du Toit, Focusing on Paul: Persuasion and Theological Design in Romans and Galatians (ed. C. Breytenbach and D. S. du Toit; BZNW 151; Berlin: de Gruyter, 2007).

11 Since there are time constraints on the preparation and the delivery of any lecture, I have selected those commentaries that are typical for a period or had a great impact. Under 'commentary' I have included paraphrases of the entire text and less comprehensive expositions, e.g. sermons and lectures. As far as possible I have consulted the original texts, but I would have lost my way in the difficult subject matter without the help of the expert work of various historians of Christianity. For studies that refer to early interpretations other than commentaries, cf. the articles in Early Patristic Readings of Romans (ed. K. L. Gaca and L. L. Welborn; Romans through History and Cultures Series; New York: T\&T Clark, 2005) by M. J. Brown, 'Jewish Salvation in Romans according 
on the way in which they understand Christ's death in Romans 3:25-26 and 5:6-8.

Some early writings used Romans, for instance the letter to the Ephesians ${ }^{12}$ and the letter Clement wrote to the Corinthians in A.D. 96. ${ }^{13}$ By the end of the $2^{\text {nd }}$ century the first commentaries on Paul's letter were written. Unfortunately most of them survived only amongst the catenae. ${ }^{14}$ The first extant commentary on the letter to the Romans is that of Origen. He wrote it A.D. 243-244, shortly before his commentary on Matthew. The commentary came to us in the Latin translation of Rufinus of Aquileia, completed at the beginning of the $5^{\text {th }}$ century. Fortunately there are Greek fragments, allowing us to get an impression of Origen's choice of Greek words and his style. ${ }^{15}$ Important are the extant parts of the commentary to Romans 3:5-5:7 in the Cairo Papyrus. ${ }^{16}$ Even though Origen interprets Romans through the lens of a Johannine tainted logos theology, he tries to take the literal sense of the passages seriously. ${ }^{17}$ On the basis of his

to Clement of Alexandria in Stromateis 2' (42-62), L. L. Welborn, 'The Soteriology of Romans in Clement of Alexandria, Stromateis 2: Faith, Fear, and Assimilation to God' (66-83), S. L. Graham, 'Irenaeus as Reader of Romans 9-11: Olive Branches' (87-113), D. J. Bingham, 'Irenaeus Reads Romans 8: Resurrection and Renovation' (114-132), and R. Clements, 'Origen's Readings of Romans in Peri Archon: (Re)Constructing Paul' (159-179).

12 In recent years the hypothesis that Ephesians utilized the letter to the Colossians have gained field. Interesting, though, is that those parts of the letter to the Ephesians that go beyond Colossians, e.g. the sections on the unity of the church in Ephesians 2:110, 11-13 and 4:1-16, 25, take up Romans 3:24-25 and 11:18; 9:4-5 and 12:1, 3 and 5 respectively. Cf. M. Gese, Das Vermächtnis des Apostels: Die Rezeption der paulinischen Theologie im Epheserbrief (WUNT 2/99; Tübingen: Mohr Siebeck, 1997).

13 Cf. Romans 1:29-32 and 5:12-6:2 in 1 Clem. 32:4-33:1 and 35:5-6. For details see A. Lindemann, Paulus im ältesten Christentum: Das Bild des Apostels und die Rezeption der paulinischen Theologie in der frühchristlichen Literatur bis Marcion (BHT 58; Tübingen: Mohr, 1979), pp. 185-187.

14 Cf. A. Souter, The Earliest Latin Commentaries on the Epistles of St. Paul: A Study (Oxford: Clarendon, 1927); K. Staab, ed., Pauluskommentare aus der griechischen Kirche (NTAbh 15; Münster: Aschendorff, 1933).

15 Cf. C. P. Hammond Bammel, Der Römerbrieftext des Rufin und seine Origenes Übersetzung (AGLB 10; Freiburg: Herder, 1985), pp. 18-43.

16 P. Cairo 88748 (+ cod. Vat. Gr. 762) (Scherer).

17 Paraphrasing the text, he broke the long Greek periods Paul had constructed down into shorter sentences, easier to comprehend. Cf. T. Heither, introduction to Origenes, Commentarii in epistulam ad Romanos/Römerbriefkommentar (Fontes Christiani 2,1; Freiburg: Herder, 1990), pp. 24-25. 
philological investigation, he then turns to the inner meaning. Following 1 Corinthians 2:12-16 he aims at explaining the understanding of the spirit. Only the exegete filled with the Holy Spirit can uncover the spiritual meaning of the text.

When commenting on Rom 3:25-26, Origen approaches the text from Heb 9:26 and states that at the end of time God set Christ up to make

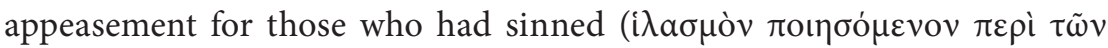
$\dot{\eta} \mu \alpha \rho \tau \eta \kappa o ́ \tau \omega \nu)$. The purpose of this was to destroy the old nature of the

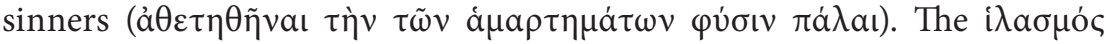
only benefits those who believe. ${ }^{18}$ Origen is of the opinion that Paul took the word i $\lambda \alpha \sigma \tau \lambda$ ńpiov in Rom 3:25, which means "place of appeasement",

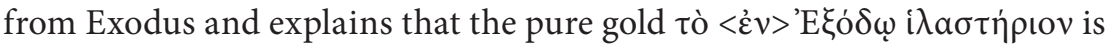
meant allegorically, referring to no one else than the Savior. Like the golden

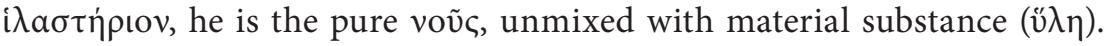
Amending John 1:1, 1 Pet 2:22 and 2 Cor 5:21, Origen summarizes: "Such is our propitiation, God, in the beginning God, the Word. Or perhaps better the psyche of Jesus, because he did no sin, no guile was found in his mouth and he knew no sin. ${ }^{19}$ The way in which Jesus accomplished

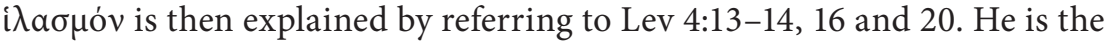
place of propitiation (i $\lambda \alpha \sigma \tau \eta \dot{\rho} \rho \mathbf{v}$ ), the priest and the one who is sacrificed for the people. ${ }^{20}$ Because he is the victim too, his bloodshed is the force

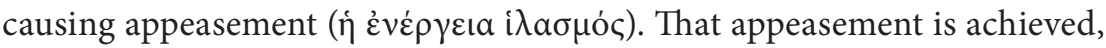
is illustrated through the forgiveness of previously committed sins. The i $\lambda \alpha \sigma \mu$ ó $\zeta$ is thus concession and remittance of committed sins for those who believe. $^{21}$

Origen was confronted with Marcion's heresy dislodging Christianity from its Jewish roots. He permanently uses the law and the prophets to interpret

18 P. Cairo 88748 (Scherer, 156.5-6).

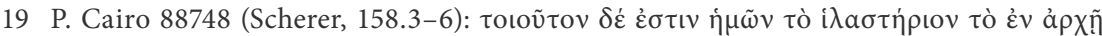

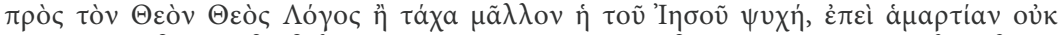

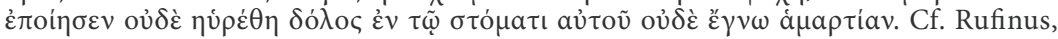
Orig. Comm. Rom. III.5 (8) (AGLB 16:238; PG 14:947b).

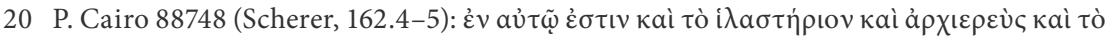

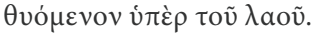

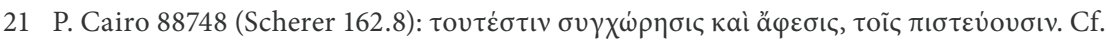
Rufinus,Orig. Comm. Rom. III.5 (8) (AGLB 16:243; PG 14:950a). 
Paul. In the process however, he has initiated an understanding of the death of Christ in Paul's letters from Exodus, Leviticus, Hebrews and the first letter of John. As can be seen from Rufinus' translation of his commentary on Romans 5:8, Origen has a clear idea that the notion that 'Christ died for our sins' had various parallels in Greek tradition. He correctly marks the major difference between the Greek heroes and Christ. None of those about whom it is told that they gave their lives for their cities or their nations are said to have taken away the sins of the whole world. ${ }^{22}$ Although Origen realizes that Paul has used the Greek conception of 'dying for someone', he moves the focus from the background of Paul's language to the cultic traditions within the Old Testament when explaining how Christ's death has an effect. It would take theology long to disentangle this conflation of ideas and to rediscover the metaphorical background Paul himself had in mind. ${ }^{23}$

For an overall tendency of the commentary we have to adhere to Rufinus' translation of Origen's commentary. Origen's understanding of Paul's theology presupposes the unity of God. Defending Paul against Marcion and the Gnostics, he illustrates Paul's endeavours to underline the unity between the old and the new covenants. Paul was confronted with a fundamental problem. As ethnic group the Jews were those who carried the veneration of God. Now, that all of humankind worshipped him, this religion had to be translated. According to Origen (and Rufinus' translation) Paul teaches how religion is translated: from the Jews to the Gentiles, from circumcision to faith, from shade to truth, from following the law in the flesh to following the law in the Spirit. ${ }^{24}$ Circumcision, which was the external sign of belonging to the old covenant, is translated into the circumcision of the heart, an internal sign of an internal reality of faith. Paul 'wants to show either how salvation came to those who lived according to the law before the coming of Christ or how, on the basis of Israel's unbelief, salvation would be bestowed upon the Gentiles through

22 Rufinus, Orig. Comm. Rom. IV.11 (AGLB 33:351; PG 14:1000c): Nullus tamen ipsorum de quibus ista narrantur ne fictio quidem sermone totius mundi peccata absoluisse perhibetur nisi Iesus solus. Cf. also Origen, Cels. 1.31.

23 Cf. my essays in C. Breytenbach, Grace, Reconciliation, and Concord: The Death of Christ in Graeco-Roman Metaphors (NovTSup 135; Leiden: Brill, 2010).

24 Cf. Rufinus, Orig. Comm. Rom. IX.1 (AGLB 34:710; PG 14:1202-1203a). 
the coming of the Saviour. ${ }^{25}$ Not only those Gentiles who believe come to salvation, nor is the entire nation of Israel rejected, a remnant of believers are being saved. Throughout his exposition Origen takes up Paul's legacy in Romans which addresses specifically the problem of the unity of the believers from the true Israel and nations. Notwithstanding Rufinus' translation, Western Christianity would need more than a century and a half to rediscover the importance of Paul's letter to the Romans for the wild olive plant called Christianity and to realize that it cannot live without the Jewish root that carries it.

John Chrysostom (A.D. 349-409) had unbridled admiration for Paul. He called Paul the heavenly trumpet. His commentary on the letter to the Romans consists of thirty two sermons (homilies) on the letter. ${ }^{26}$ Chrysostom realized that regarding the time in which a specific letter was written helps to understand the letter. Using Acts and the letters to the Corinthians and the letter to the Romans as basis, Chrysostom argues in the first introductory homily that Paul wrote the letter to the Romans after those to the Corinthians and to the Galatians, after his last journey to Jerusalem, when he was already on his way to Rome. ${ }^{27}$ Paul could not yet visit the Romans, he thus wrote the letter to show them the right way and to announce that he would visit them in person. ${ }^{28}$ When Chrysostom turns to Romans 3:24-25 in his eighth homily, he mentions various reasons for Paul's statement that those who were enslaved by sin, are now, as a free gift, justified by God's grace through the redemption in Christ. It is God who can do everything, justification comes from him. It happens without the law. But how is the redemption, which ends the slavery caused by sin, brought about? Chrysostom follows the line of Origen and interprets the

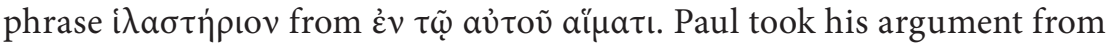
the sacrifices from the "Old" (Testament). With 'in his blood' he reminds

25 Rufinus, Orig. Comm. Rom. III.1 (AGLB 16:193; PG 14:923a) (trans. Scheck).

26 Cf. C. A. Hall, 'John Chrysostom,' in Greenman and Larsen, Reading Romans, pp. 3957.

27 From Rome he then wrote Phil, Heb, Col, and Phlm.

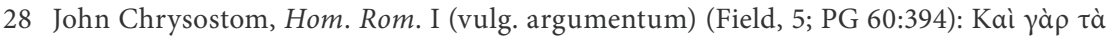

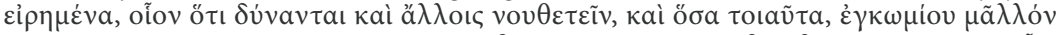

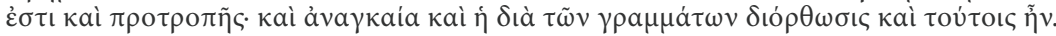

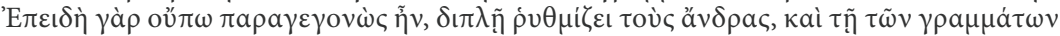

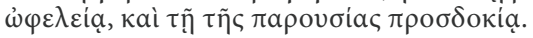


the Romans of the sacrifices of sheep and young bulls familiar to them. It is clear that Chrysostom understands the death of Christ as a sacrifice when he remarks that if the slaughtering of irrational (animals) could release from sin how much more would the blood of Christ. ${ }^{29}$ For our next author, the death of Christ was less important.

After becoming a priest in the beginning of A.D. 391, Augustine met Christian brothers in Carthage and answered their questions on Romans. They asked him to write his answers down, which he did in his opusculum during the summer and fall of A.D. 394. The work has the title Expositio quarundam propositionum ex epistula apostoli ad Romanos. Paul's letter to the Romans thus stands at the beginning of Augustine's academic career as a Christian. In his 'Propositions from the Epistle to the Romans' Augustine gives an exposition of 113 verses only. ${ }^{30}$ Many of them are merely paraphrased, but there is extensive exposition of central lines from Romans 7-9. The exposition of these chapters makes up almost half of the work.

For Augustine Romans is about the relationship between the works of the law (lex) and grace (gratia). Commenting on Romans 3:2, he explains that Paul neither condemns the law nor does he take away the free will. Before the law (ante legem), humans pursue the desire of flesh (concupiscentiam carnis), under the law (sub lege) they are pulled by it. Under grace (sub gratia) they are neither pursuing it, nor pulled by it. In eternal peace (in pace) there is no desire of the flesh (Exp. prop. Rom 13-18:2). Augustine skips the sections on Christ's death in 3:21-26, returning to verse 31: 'Do we then cancel this law through faith? By no means.' He selects those verses from chapters 4-6 that deal with the law and grace (Exp.prop. Rom. 19-35 on Rom 4:2, 4, 15, 17, 20;5:3, 6, 13-20; 6:1-2, 6, 14), again not saying a word about the meaning of the death of Christ.

Commenting extensively on Romans 7, he argues that the law is good, but it cannot give the power to do well. It merely uncovers evil and guilt (Exp. prop. Rom. 36-40, 44-46). One interesting detail: For Augustine the 'I'

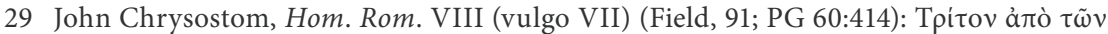

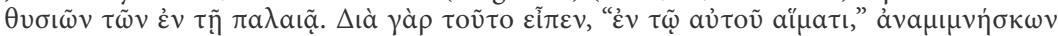

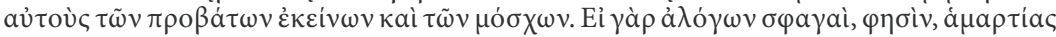

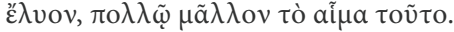

30 Cf. P. Bright, 'Augustine,' in Greenman and Larsen, Reading Romans, pp. 59-80. 
in Romans 7 is the human under the law (sub lege). In his exposition on 7:15 he says: 'The man described here is under the Law, prior to grace; sin overcomes him when by his own strength he attempts to live righteously without the aid of God's liberating grace. ${ }^{31}$ For the benefit of his addressees Paul slipped into this role. The first person does not refer to Paul himself sub gratia. Had Luther followed his Augustinian tradition, the simul iustus et peccator wouldn't have entered the Reformation claiming Paul's authority.

In an extensive discussion of Romans 9:11-15, Augustine discusses the problem of freedom of will (Exp. prop. Rom. 60-61). Having the freedom of decision, the believer (sub gratia) is never free from the power of evil until the body is transformed during the resurrection and one arrives in the final stage in complete peace (in pace). The argument runs as follows: Good works are not one's own, as the result of love they are caused by the Holy Spirit and hence a gift of God. But who receives the Spirit? Those elected by God. But who is elected? Within the context of the divine vocation, the human decision to believe is a precondition to receive grace. God chooses those, who, in his foreknowledge he knows, will believe in him (Exp.prop. Rom. 60.11).

After having completed the Expositio in A.D. 394, Augustine began a commentary on Romans. The question of the letter based on its literal context is 'whether the Gospel of our Lord Jesus Christ came to the Jews alone because of their merits through the works of the Law, or whether the justification of faith which is in Christ Jesus came to all nations, without any preceding merits for works. In this last instance, people would believe not because they were just but, justified through belief, they would then begin to live justly. ${ }^{32}$ The next sentence summarizes what the apostle intends to

31 Augustine, Exp. prop. Rom. 44.2 (CSEL 84:19; PL 35:2071): Nunc enim homo describitur sub lege positus ante gratiam, tunc enim peccatis vincitur, dum viribus suis iuste vivere conatur sine adiutorio liberantis gratiae dei.(Trans. Landes).

32 Augustine, Rom. inch. exp. 1.1 (CSEL 84:145; PL 35:2087): ... utrum Iudaeis solis evangelium domini nostri Iesu Christi venerit propter merita operum legis, an vero nullis operum meritis praecedentibus omnibus gentibus venerit iustificatio fidei, quae est in Christo Iesu, ut non, quia iusti erant homines, crederent, sed credendo iustificati deinceps iuste vivere inciperent. (Trans. Landes). 
teach: 'that the grace of the Gospel of our Lord Jesus Christ came to all men. ${ }^{33}$ This is why it is called grace. It was given freely (gratuito datum).

It is not possible to give a full account of Augustine's doctrine of grace in the Propositions or in the unfinished Exposition here. But although Augustine's reflections on the topic set in before commenting on Romans ${ }^{34}$ and he modified his doctrine of grace in his later writings, the letter caused decisive development in his thought and is the main source of his doctrine of grace, ${ }^{35}$ which became so influential in the history of the Western church, deeply influencing Peter Abelard, Thomas Aquinas and Martin Luther. ${ }^{36}$

Unfortunately Augustine never finished his commentary. For those illustrious scholars who have to add the subtitle inchoata expositio to their work on Paul's letter to the Romans, it might be comforting that Augustine heads the list.

That full commentaries on Romans were not the order of the day is illustrated by the fact that next we have to move on as far as to medieval France to Peter Abelard. It was only at the end of his sad life, after Heloise, after his ordeal at St. Denis, between 1133 and 1137 in Paris, that Abelard wrote annotations on the Latin text of Romans. ${ }^{37}$ Following the state of exegetical art of his time, the sensus litteralis was complemented with the moral and mythical sense of the text. In the special prologue on the letter Abelard explains that Paul wrote the letter to the Romans to call

33 Augustine, Rom. inch. exp. 1.2 (CSEL 84:145; PL 35:2087): Hoc ergo docere intendit apostolus omnibus venisse gratiam evangelii domini nostri Iesu Christi. (Trans. Landes).

34 Cf. V. H. Drecoll, Die Entstehung der Gnadenlehre Augustins (BHT 109; Tübingen: Mohr Siebeck, 1999).

35 Cf. T. G. Ring, 'Expositio quarundam propositionum ex epistula apostoli ad Romanos,' Augustinus Lexikon 2:1209-1218, 1213.

36 Cf. L. Karfíková, 'Zur Rezeption Augustins bei Peter Abaelard (ca. 1079-1142)', in Von den Anfängen bis zur Reformation (vol. 1 of Augustinus: Spuren und Spiegelungen seines Denkens; ed. N. Fischer; Hamburg: Meiner, 2009), pp. 71-83; T. Fliethmann, 'Augustinische Akzente in der Gotteslehre des Thomas von Aquin (1224/5-1274)', ibid., pp. 127-139. On Luther see below.

37 The glosses of Abelard are a kind of reading manual: Sic construe (construct in this way), sic lege (read like this), sic expone (render like this). Paraphrases help the reader to understand difficult passages and Abelard draws attention to the structure and flow of Paul's argument. Cf. R. Peppermüller, introduction to Abaelard, Expositio in epistolam ad Romanos/Römerbriefkommentar (Fontes Christiani 26,1; Freiburg: Herder, 2000), p. 23. 
the Romans who converted from Jews and Gentiles back to true humility (vera humilitas) and brotherly concord (fraterna concordia). ${ }^{38} \mathrm{He}$ achieves this by underlining the grace of God and by diminishing the merit of our works (opera) in order that nobody can boast their good works but rather attribute everything they achieve to divine grace. Abelard recognized that Paul took turns to attack the Jews and the Gentiles, directing his letter against the primal vice, the root of all others, quod est superbia.

Abelard opens his exposition of Romans $3: 24-26^{39}$ with the questions: What is the redemption through the death of Christ (quae sit videlicet ista nostra redemptio per mortem Christi)? In which way are we justified in his blood (quomodo nos in eius sanguine iustificari)? After a long discussion of counter positions he answers from Romans 5:5, 8 that the love of God, which Christ showed in his passion, binds us to God. ${ }^{40}$ Through the grace of Christ's incarnation and passion love springs up within the believer. It is this love which frees from the servitude of sin and acquires the true freedom of the children of God. In Romans 5:5-6 Paul expresses the way of the redemption. ${ }^{41}$ 'Christ died for us' for no other reason as to propagate true freedom of love within us. Through the death of Christ for us when we were still sinners (Rom 5:8), God builds or confirms (aedificat sive confirmat) his love in us. It is this love evoked by Christ's love in dying for the sinners that justifies them. By understanding the phrase 'in his blood' (in sanguine suo) in Romans 5:9 as per dilectionem ('through love'), Abelard has explained the effect of the death of Christ without introducing sacrificial categories, and recaptured the spirit of Paul's original metaphor in Romans 5:6, 8. ${ }^{42} \mathrm{It}$ took a long process of historical critical research to re-arrive at this point.

In the footsteps of Augustine, the whole doctrine of the Pauline letters (including Hebrews) is for Thomas Aquinas on the gratia Christi. The letters directed to the gentiles are specifically about the grace in the mystical body of Christ, the church. The letter to the Romans teaches grace itself and combats, as expressed in Romans 16:1 pride (hic confutabatur superbia

38 Cf. Abelard, Comm. Rom., Prologus (CCCM 11:43; PL 178:785c).

39 Cf. Abelard, Comm. Rom. II (III, 26) (CCCM 11:113; PL 178:833d).

40 Cf. Abelard, Comm. Rom. II (III, 26) (CCCM 11:118; PL 178:836c).

41 Cf. Abelard, Comm. Rom. II (V, 5-6) (CCCM 11:155; PL 178:860b-c).

42 Cf. Abelard, Comm. Rom. II (V, 7-9) (CCCM 11:155-156; PL 178:860d-861a). 
quae est 'initium omnis peccati'). ${ }^{43}$ When commenting on Romans in Naples in the years $1272-1273^{44}$ Thomas Aquinas introduces the doctrine of satisfaction. In his comment on Romans 3:24-25 he states that the cause of justification is redemption. ${ }^{45}$ Citing John 8:34 he argues, who sins, is a slave of sin. Redemption from this slavery presupposes satisfaction for $\sin$ and satisfaction for the sin of the total human race could only be made by Christ, who is immune from all sin (unde nullus alius pro peccato totius humani generis satisfacere poterat, nisi solus Christus qui ab omni peccato erat immunis). Christ makes satisfaction for us, in the sense that he undergoes the punishment for the sins human committed (ut enim pro nobis satisfaceret, congruebat ut poenam mortis pro nobis subiret, quam homo per peccatum incurrerat). This is why according to Romans 4:24 the redemption is in Christ Jesus: God himself gave Christ to redeem and to make satisfaction. According to Romans 3:25, the satisfaction by Christ has the effect to justify and redeem, for God set him up as propitiation (ex hoc enim Christi satisfactio efficaciam ad iustificandum habuit, et ad redimendum, quiaeum Deus ad hoc ordinaveratsecundum suum propositum, quod designat cum dicit 'quem proposuit Deus propitiatorem'). As figura for Christ, who is set up upon the church, the propitiatorium in Exodus 25:17 is upon the ark (in cuius figura, Ex. XXV, v. 17, mandatur quod fiat propitiatorium, id est quod Christus ponatur super arcam, id est, Ecclesiam). By believing in his blood, the effect of Christ's redemption comes to us. Thomas understands Romans 4:25 (that Christ was delivered unto death because of our wrongdoing) in the sense that through his death he earned us the acquittal of $\sin$ (sua morte meruit nobis deletionem peccatorum).$^{46}$ Romans 5:6-8 is understood in the light of 3:25. From his exposition of the passage, it becomes clear that - with reference to John 3:16 - he sees the death of Christ for the sinners rooted in the immense grace of God: 'This death of Christ for us demonstrates the grace of God, because he delivers his Son, in order to make satisfaction for us through his death' (ipsa autem

43 Thomas Aquinas, Ad Rom., Prologus (Cai, 12).

44 Cf. T. Domanyi, Der Römerbriefkommentar des Thomas von Aquin: Ein Beitrag zur Untersuchung seiner Auslegungsmethoden (Basler und Berner Studien zur historischen und systematischen Theologie 39; Basel: Peter Lang, 1979), pp. 39-41. See also S. Boguslawski, 'Thomas Aquinas,' in Greenman and Larsen, Reading Romans, pp. 81-99.

45 Thomas Aquinas, Ad Rom. III lect. 3 (Cai, 307-310).

46 Thomas Aquinas, Ad Rom. IV lect. 3 (Cai, 380). 
mors Christi pro nobis charitatem ostendit Dei, quia dedit Filium suum, ut pro nobis satisfaciens moreretur). ${ }^{47}$

It is by common consent accepted that the historical investigation of the letter to the Romans starts 1836 with Ferdinand Christian Baur. ${ }^{48}$ I was thus surprised to read through the summary of the argument with which Desiderius Erasmus introduced his paraphrases of Paul's letter to the Romans in 1517 - a year after he had translated the New Testament from Greek into Latin for his edition which was to become the textus receptus of the Novum Testamentum Graece. Erasmus' paraphrase is the first commentary on the Greek text of Paul's letter since Origen. ${ }^{49} \mathrm{He}$ argues that the Roman Christians, Jews and Gentiles were wrongly instructed by pseudo apostles. In the early stages of the church there were those who believed that the gospel should not be propagated amongst the heathens. Such grace, so they argued, was reserved for the descendants of Abraham and the Jewish people. ${ }^{50}$ Since the Jews will never give up their religion and the Greeks and the Romans will never accept the Jewish law, Paul 'takes special pains everywhere to annul and to reject the ceremonies of the law and to transfer to Christ alone all hope for obtaining salvation ... he prepares and fortifies the Romans that they might not become careless and be trapped by the pseudo apostles ... but would persist instead in the right teaching which they had begun to embrace. ${ }^{51}$ Paul is afraid that the pseudo apostles will regain influence in Rome and thus aims his message at both, Jews and Gentiles, in Rome. By highlighting the supreme love of God

47 Thomas Aquinas, Ad Rom. V lect. 2 (Cai, 399).

48 Cf. F. C. Baur, 'Über Zweck und Veranlassung des Römerbriefes und der damit zusammenhängenden Verhältnisse der römischen Gemeinde', Tübinger Zeitschrift für Theologie (1836): pp. 59-178.

49 Erasmus used the commentary of Origen.

50 With reference to the Cornelius episode in Acts 10, Erasmus argues that even Peter was not unsympathetic to this view until he was warned through a vision. In Jerusalem there were those who would not allow the Gentiles to have partnership in the Gospel unless they were circumcised according to the Jewish rite. 'They were assuming that Christ needed the support of the Mosaic Law, and at the same time they wished to transfer the glory of the gospel to their own race.' (Erasmus, Ad Rom. VII.774 (Leclerc) (trans. Payne)). Erasmus noted that in Antioch the gospel was preached to the Jews only. With an anti-Judaic undertone Erasmus mobilizes the evidence from the apostles' meeting in Jerusalem, the incident in Antioch between Paul and Peter, the circumcision of Timothy, Paul's vow according to Acts 21 and even Josephus' Antiquitates, to argue that the Jews tenaciously held on to their own religion.

51 Erasmus, Ad Rom. VII.775-776 (Leclerc) (trans. Payne). 
for all in the death of Christ, he argues that God opened up an approach to the grace of the gospel 'through the intervention of faith ... without the assistance of the law or circumcision. ${ }^{52}$ But the letter is not easy to read, not even for Erasmus, for Paul first considers the Jews, then the Gentiles, then both.

Commenting on Romans 3:21-26, Erasmus states the justification is given 'freely by the divine goodness ... through Jesus Christ by whose blood we have been redeemed from the tyranny of sin. ${ }^{53}$ Drawing on Romans 5:10 he explains that God has revealed 'that Christ is the true propitiation for all, in order that we, formerly hostile on account of our sins, now might be reconciled to God, not (as with the Jews) through the blood of beasts, but through the most holy blood of Christ himself, which washes away all the sins of all people. ${ }^{54}$ Erasmus can also formulate that it is God who is hostile towards men because of their sins, and he is reconciled by the blood and death of Christ. ${ }^{55}$ Taking up Romans 3:26 again he explains the function of Christ's death: 'In this way he reveals his righteousness to all men, while through the Son he pardons the errors of their former life with the intent that they afterwards do not fall back again into sin. ${ }^{56}$ In his periphrasis of Romans 5:6-8, very much in the vein of Abelard, Erasmus underlines God's unconditional love for the ungodly. 'God has surpassed all examples of human love, because he handed over his Son to death for the impious and the unworthy. ${ }^{57}$

Erasmus dedicated his annotations on Romans to Grimani of Venice, the Cardinal of St. Mark's. The manuscript must have been finished before the dedicatory letter was written. It is dated Leiden, November 13, 1517, only thirteen days after Luther's 95 theses were put up in Wittenberg. Erasmus' historical approach had to wait more than three centuries to be recovered by Baur, but he made a re-start to study Paul's legacy to theology in the original and against its historical background. Erasmus read Romans

52 Erasmus, Ad Rom. VII.792 (Leclerc) (trans. Payne).

53 Erasmus, Ad. Rom. VII.787 (Leclerc) (trans. Payne).

54 Erasmus, Ad Rom. VII.775-776 (Leclerc) (trans. Payne).

55 Erasmus, Ad Rom. VII.791-792 (Leclerc) (trans. Payne).

56 Erasmus, Ad Rom. VII.787 (Leclerc) (trans. Payne).

57 Erasmus, Ad Rom. VII.792 (Leclerc) (trans. Payne). 
1:17 'My righteous man shall live by faith. ${ }^{58} \mathrm{He}$ distinguished two kinds of righteousness, the first Mosaic one, consisting in ceremonies like circumcision, and the second one, through faith. This righteousness is open for Jews and Gentiles. ${ }^{59}$ Luther's different reading changed the course of history.

Martin Luther's exegesis of Paul's letter to the Romans was the beginning of his theological work, but he did not leave us a commentary on Romans. He did however, after lecturing on the Psalms in 1513 to 1515 , give an exposition of the letter to the Romans in the winter of 1515 to 1516, his second exegetical lecture. ${ }^{60}$ Luther's own copy of the Vulgate - in 1515 Erasmus' edition of the Greek New Testament was not available yet - with his annotations ${ }^{61}$ and his separate exposition as well as the notes of several students survived from this lecture. ${ }^{62}$ Luther's exposition, however also presupposed his new understanding of Romans 1:17.63

He wanted to understand what is meant by the phrase that the righteousness of God is revealed in the gospel. Luther understood the iustitia dei in the normal philosophical sense as formal or active justice, a characteristic of God himself, who is just and punishes the sinners and the unjust (qua Deus est iustus, et peccatores iniustosque punit). ${ }^{64}$ Scrutinizing the context of the phrase in the Latin text, he realized that the justice of God is revealed as is written: the just lives on the basis of faith: iustus ex fide vivit. Then he started to understand the righteousness of God as the righteousness that God grants those whom he justifies. He gives them the justice that they do not have as a gift (donum) in order that they can live. ${ }^{65}$ Forty years later, in 1545, an elderly Luther looked back on this moment he understood Paul: 'Then there was for me a sense of having just been reborn and having entered

58 Erasmus, Ad Rom. VII.781 (Leclerc) (trans. Payne).

59 Erasmus, Ad Rom. VII.810-811 (Leclerc) (trans. Payne).

60 On the following, cf. D. Wendebourg, 'Der Römerbrief bei Martin Luther' in Breytenbach, Römerbrief, pp. 119-134.

61 WA 56.

62 WA 57:3-127, 129-232.

63 For a detailed treatment see Wendebourg, 'Römerbrief.'

64 WA 54:185.19-20.

65 WA 54:186.4-8. 
through the open gate paradise itself.' ${ }^{66}$ The letter to the Romans changed the way in which Luther understood himself before God. It changed his life, it initiated the Reformation, and it changed Europe and eventually a great part of the world.

This however was prepared through more study. Luther, who was a monk in the order of St. Augustine in Erfurt, started studying the works of Augustine. ${ }^{67}$ The influence of the latter's doctrine on divine grace became evident in Luther's exposition of Romans 3:24-25. All those who are justified are justified freely, 'by His, God's, grace, without merits or works. This grace is not given except through the redemption which is in Christ Jesus. ${ }^{\prime 68}$ Redemption from the enslavement by sin entails that satisfaction being made for us, we are saved (satisfaciens pro nobisque solvens).$^{69}$ Luther notes that ' $\mathrm{He}$ [God] has given Christ as the one who makes the satisfaction for us, so that He thus may still freely give His grace to those who make satisfaction through another. ${ }^{70}$ After Christ made satisfaction for us through his blood, he became a place of propitiation for those who believe. 'Therefore by His blood He is made a place of propitiation for those who believe. ${ }^{71}$ God passes over sins through the propitiation and thus justifies. By glossing Paul's text with legal categories like placare and satisfacere ${ }^{72}$ (and 'versühnen'73 in German for reconciliare in Romans 5:10) to explain the effect of the death of Christ, Luther probably imported a substantial

66 WA 54:186.8-9: Hic me prorsus renatum esse sensi, et apertis portis in ipsam paradisum intrasse.

67 That Luther read Augustine's Expositio is clear from the former's comment on Romans 5:5 where he refers to Augustine, Exp. prop. Rom. 26 (CSEL 84:10; PL 35:2067).

68 WA 56:37.12-13: ... per gratiam sine meritis et operibus ipsius/ Dei, que gratia non datur nisi per redemptionem quae est in Christo Ihesu. (Trans. Preus) (emphasis original).

69 WA 56:37.15.

70 WA 56:37.27-28, n. 4: satisfactorem Christum pro nobis dedit, ut sic satisfacientibus per alium ipsis tamen gratis gratiam daret. (Trans. Preus).

71 WA 56:38.19-20, n. 1: Ideo in sanguine suo factus est propitiatorium credentibus. (Trans. Preus).

72 WA 56:37.

73 Cf. on Romans 5:10-11: 'Denn so wyr Gotte versunet sind durch den Tod seynes sons, da wyr noch feynde waren, viel mehr, werden wyr selig werden durch seyn leben, so wyr nu versunet sind. [11] Nicht alleyn aber das, sondern wyr rhumen uns auch Gottis, durch unsern hern Jhesu Christ, durch wilchen wyr nu die versunung empfangen haben.' (WADB 7:44.5-9). 
part of Catholic dogma of the mass into Protestant theology. ${ }^{74}$ But this should not tarnish the positive impact Romans had on the life of Luther, as we can see from the initial lines of his extensive preface to Romans in the German translation of the New Testament of September $1522 .{ }^{75}$ I cite the initial lines: 'This letter is truly the most important piece in the New Testament. It is purest Gospel. It is well worth a Christian's while not only to memorize it word for word but also to occupy himself with it daily, as though it were the daily bread of the soul. It is impossible to read or to meditate on this letter too much or too well. The more one deals with it, the more precious it becomes and the better it tastes. ... Up to now it has been darkened by glosses and by many a useless comment, but it is in itself a bright light, almost bright enough to illumine the entire Scripture. ${ }^{76}$ It is worthwhile reading the whole preface which led to the conversion of John Wesley. ${ }^{77}$

Luther's lectures on Romans still followed the method on interlinear and margin notes on the Latin text. He explained and annotated the text, sometimes giving longer comments. He, however, did not do it with the same historical interest and philological acumen like Erasmus. Philipp Melanchthon introduced a change in the method of exposition of the text of Romans. Melanchthon studied Romans carefully. From the forerunner of his famous Loci of 1521, the Theologica Institutio, he explains that the first part of Romans is about faith justifying man, it is about moral law. ${ }^{78}$ He ends the Institutio with a summary of the context of Romans which contains the summa of our justification, especially the Loci de iustificatione,

74 This begs for further research.

75 Cf. Wendebourg, 'Römerbrief.'

76 WADB 7:2.3-16: „Dise Epistel ist das rechte hewbtstuckt des newen testaments, und das aller lauterst Euangelion, Wilche wol wirdig und werd ist, das sie eyn Christen mensch nicht alleyn von wort zu wort auswendig wisse. sondern teglich da mit umb gehe als mit teglichem brod der seelen, denn sie nymer kan zu viel und zu wol gelesen odder betrachtet werden, Und yhe mehr sie gehandelt wirt, yhe kostlicher sie wirt, unnd bass sie schmeckt, [...] Denn sie biss her, mit glosen und mancherley geschwetz ubel verfinstert ist, die doch an yhr selb eyn helles liecht ist, fast gnugsam die gantze schrifft zu erleuchten.' (Trans. Thornton).

77 Cf. V. Shepherd, 'John Wesley,' in Greenman and Larsen, Reading Romans, pp. 149-168, 150.

78 Cf. P. Melanchthon, Theologica Institutio in Epistolam Pauli ad Romanos (Bizer, pp. 90-99). 
de praedestinatione et vocatione und de moribus. ${ }^{79}$ Paul wanted to show Christ to the world, that he is the author or our justification and gives the spirit that justifies. ${ }^{80}$ The influence of Romans on the Loci of 1521 is obvious, even on its order. In the last section of the Institutio Melanchthon formulates the status causae of the letter to the Romans: Justification is on basis of faith, without works. ${ }^{81}$

In an overview on the letter to the Romans which stems from the notes a student of Melanchthon took in 1521, Melanchthon calls the letter

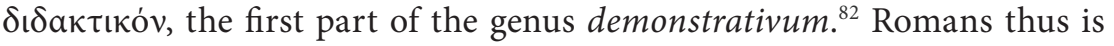
analyzed as a whole. With the method of ancient rhetoric, Melanchthon tried to reconstruct Paul's argument. He asks why the argument is made in the first instance (status causae), what was controversial. For Melanchthon justice is faith (summa iustitia est fides). The central proposition is formulated in Romans 1:16-17, and illustrated in Romans 1:18-3:20. In Romans 5 a new book is started, 6:1-7:6 being a digression, chapter 8 on the new life recapping and concluding Romans 5:1-11, 12-21. According to Melanchthon Paul could have stopped here, but since he wanted to treat the topic of predestination, Romans 9-11 is added. In the summer of 1522 Melanchthon then lectured on Romans. Luther published these Annotations of Melanchthon which became very influential. They were used by Bullinger and Calvin.

One must give Melanchthon credit for analysing the whole of the letter as an argument. He moved well beyond the mere annotations of Luther. It would have been of help if those who rediscovered the rhetorical analysis

79 Cf. E. Bizer, introduction to Artifitium Epistolae Pauli ad Romanos a Philippo Melanchthone, in E. Bizer, ed., Texte aus der Anfangszeit Melanchthons (Texte zur Geschichte der evangelischen Theologie 2; Neukirchen-Vluyn: Neukirchener Verlag, 1966), pp. 10-11.

80 E. Bizer, Theologie der Verheißung: Studien zur theologischen Entwicklung des jungen Melanchthon (1519 - 1524) (Neukirchen-Vluyn: Neukirchener Verlag, 1964), pp. 36-37.

81 Melanchthon stated that the letter belongs to the judicial genre, having an exordium, narrationem, and confirmationem. The narration goes from Romans 1:18 to 3:31 and is interrupted by two digressions in chapters two and three (from Rom 3:9 onwards). Romans 3:21-31 summarizes the argument until the confirmation with the example of Abraham in Romans 4 sets in. Cf. Bizer, introduction to Artifitium, p. 11.

82 Cf. P. Melanchthon, Artifitium Epistolae Pauli ad Romanos (Bizer), p. 20. 
of Paul's letters would have taken cognizance of Melanchthon's efforts. ${ }^{83}$ One the other hand, the interaction between Melanchthon's study of the Romans and his Loci Communes of 1521 is clear. This initial dogmatic of the Reformation, which - according to Luther - could have been part of the canon, would not have been possible without Romans. For the letter to the Romans it had the consequence that it would be studied as a theological treatise, somewhat disconnected from its historical context, Romans 9-11 being on predestination. The insights of Origen and Erasmus were lost and notwithstanding Baur's warning of 1832 to study the letter as an historical document, we had to wait until the end of the $20^{\text {th }}$ century for this to become the state of art.

After the $2^{\text {nd }}$ edition of his Christianae Religionis Institutio of 1539 John Calvin published a commentary on Romans in 1540. Calvin was of the opinion 'that the chief excellency of an expounder consists in lucid brevity.' The commentator has to expose the mind of the author. He thus has 'to avoid the evil of tiring his readers with prolixity' (preface). For Calvin there is method in the letter, which centres on the principal topic, that we are justified by faith (chapters 1-4). He states the subject then of these chapters as follows: 'man's only righteousness is through the mercy of God in Christ, which being offered by the Gospel is apprehended by faith. ${ }^{84}$ The way in which Calvin summarizes the argument of the letter shows that he is more interested in the theological themes in the letter. ${ }^{85}$ Unlike

83 C. J. Classen, 'Paulus und die antike Rhetorik,' ZNW 82 (1991): pp. 1-33.

84 Cf. Calvin, Comm. Rom., Argumentum (Parker, 5): Unicam esse hominibus iustitiam, Dei misericordiam in Christo, dum per Euangelium oblate, fide apprehenditur. (Trans. Owen).

85 But since human beings are so overconfident that they do not think that they need the righteousness of faith and are 'inebriated with the sweetness of lusts' Paul in Romans 1-3 proceeds to convince both Jews and gentiles of their iniquity and to shake off the inactivity of those whom he proves guilty. At the end of chapter three he then returns to his main subject, 'that we are justified by faith; and he explains what faith is and how the righteousness of Christ is by it attained by us.' By way of the example of Abraham he then argues that Abraham was justified by faith and excludes any other means of justification. '[T] he righteousness of works ceases to exist, since the righteousness of faith is introduced.' In ch. 5, 'after having touched on the fruit and effects of the righteousness of faith, he is almost wholly taken up with illustrations, in order to make the point clearer.' Reasoning from baptism Romans 6 is about the sanctification obtained in Christ. '[W]ithout regeneration no one can put on his righteousness.' Ch. 7 is a full discussion of the law, ch. 8 is giving consolation, 9-11 treats the rejection of Christ by the Jews, 12-14 are giving admonition, ch. 15 begins by repeating the 
Origen, Augustine, and Erasmus, he does not try to understand the letter from an historical situation. Following Melanchthon, he treats the letter as a timeless theological treatise.

In his exposition of Romans 3:24 Calvin introduces the theory of satisfaction. By his obedience Christ satisfied the Father's justice (quod sua obedientia Christus Patris iudicio satisfecit) on account of the sacrifice which he brought as recompense, our quilt is removed (Nam sacrificii quod obtulit, expiatione, sublatus est noster reatus). What is this redemption? Its object is to reconcile us to God (ut Deo reconciliemur). Christ is a propitiation. The Christians are justified, Calvin argues, as far as Christ appeases the Father for them. By introducing the notion of satisfaction and of appeasing God's anger by means of a propitiation, Calvin introduces concepts into the text of Romans foreign to Paul's Greek, as can be seen from the exposition of Romans 3:25: 'Paul refers to the gratuitous mercy of God, in having appointed Christ as our Mediator, that he might appease the Father by the sacrifice of his death: nor is it a small commendation of God's grace that he, of his own good will, sought out a way by which he might remove our curse.' One cannot deny that this way of argument falls back behind Augustine's view on the grace and Abelard's focus on the love of God.

Last but not least, and very briefly, we come to Karl Barth, one of the teachers of Andrie du Toit himself. Still a pastor in Safenwil, Barth and his friend Eduard Thurneysen started a new beginning in theology. From 1916 to 1921 Barth spent every free minute with Paul's letter to the Romans. ${ }^{86}$ When the weather permitted it, he worked under the apple tree in the parish garden. Barth's translation and continuous commentary of the letter appeared in 1919: a tour de force against subjective theology. ${ }^{87}$ In the $2^{\text {nd }}$ edition of 1922 Barth further developed his theology in close reading of the letter to the Romans. ${ }^{88}$ The text led him to make God the

argument 'as a conclusion of the whole subject.' The salvation of both, the strong and the weak, rests on the mercy of God alone.

86 On the following see F. Lohmann, 'Die Krisis des Glaubens: Karl Barths Auslegung des Römerbriefes,' in Breytenbach, Römerbrief, pp. 135-160.

87 Cf. K. Barth, Der Römerbrief (Erste Fassung) 1919 (ed. H. Schmidt; Karl BarthGesamtausgabe 2; Zürich: TVZ, 1985).

88 Cf. K. Barth, Der Römerbrief (Zweite Fassung) 1922 (ed. C. van der Kooi and K. Tolstaja; Karl Barth-Gesamtausgabe 2; Zürich: TVZ, 2010). 
point of departure of his thoughts, to respect God's sovereignty. God can only be known by God, therefore man must allow the freedom of God to reshape his life. 'God is in heaven, you are earth.' Central themes of Barth's theology, like the sovereignty of God, his trustworthiness, God's freedom of grace and the continuity in his election since the beginnings of Israel, all have their equivalents in Romans.

In his exposition on Romans 5:6 for example, Barth notes that grace is not something man experiences. Religious experience would be a form of human work. Grace is a precondition which God creates, a new order into which humans are taken. ${ }^{89}$ Faith also does not have its foundation in human consciousness, it is trust in God. Barth translates Romans 3:28 'Denn wir halten dafür, daß der Mensch durch die Treue Gottes gerecht wird, abgesehen von dem Handeln, zu dem das Gesetz auffordert. ${ }^{\text {'90 God's }}$ trustworthiness opposes human religion.

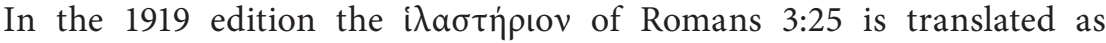
'Sühnungsgabe'. Until the advent of God's righteousness, religious actions like sacrifice, prayer and sermons could have led to repentance. Building on the premise that in wrath God opposes the world, these were religious efforts to appease God ('Versuche, Gott zu versöhnen'). ${ }^{91}$ When God's faithfulness towards man was revealed, he broke the power of sin beyond religion. He himself gave Christ as the 'Sühnungsgabe' that all piety intended to bring. Religious devotion and action thus become senseless. Because God already has given everything needed. Barth interprets the 'Sühnung' as 'Versöhnung' when he formulates: 'Die göttliche Versöhnungsgabe ist das Ende aller menschlichen. ${ }^{.92}$ Being God's gift of reconciliation Christ completes and ends all religion.

In the second edition Barth builds on these stones. Drawing on the 'Kapporeth' in Exodus 25:17-21, he now translates 'hilastērion' with 'Versöhnungsdecke'. God lives above this place. Here the comparison with Jesus lies: 'Als solcher Ort, über dem Gott wohnt, von wo aus er redet, als Ort der Versöhnung ist Jesus von Ewigkeit her im Ratschlusse Gottes

89 Barth, Römerbrief (Erste Fassung), pp. 159-162.

90 Barth, Römerbrief (Erste Fassung), p. 101.

91 Barth, Römerbrief (Erste Fassung), p. 97.

92 Barth, Römerbrief (Erste Fassung), p. 98. 
bestimmt und jetzt, in der Zeit, vor die Menschen hin, in die Geschichte hineingestellt. ${ }^{\prime 93}$ Assuming that i $\lambda \alpha \dot{\sigma} \sigma \varepsilon \sigma \theta \theta$ a (to make or to be placid)

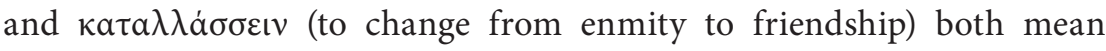
'versöhnen,' and mistranslating 2 Corinthians 5:19 ('Gott war in Christus tätig zur Versöhnung der Welt mit sich selbst.'), Barth interprets Romans 3:25 as 'Ort der Versöhnung'. For the purpose of reconciliation, God loaded and undermined Jesus' life. In this place, God's kingdom came close. Here the redemptive power of his advent is experienced.

The importance of 'Versöhnung' (reconciliation) in Barth's work is built on the conflation of the concepts of 'Sühnung' and 'Versöhnung,' which marks German theology since Luther's translation ${ }^{94}$ It took more than half a century until Ernst Käsemann illustrated in 1967 that Paul's theology is gravely misrepresented if one takes 'Versöhnung and Sühne' as its leading category. ${ }^{95}$

Thanks to Andrie du Toit, Käsemann's 'An die Römer' was the first German book I read in my life. ${ }^{96}$ I remembered how he praised it saying that Käsemann wrote this landmark work in great love for Paul's letter. Even if his answers on the reasons for the writing of Romans are less satisfactory, Käsemann's 'An die Römer' would pave my way in understanding Paul's legacy to Christianity for the years to come. ${ }^{97}$ Origen and the unity of Jewish and non-Jewish Christians, Augustine and the primacy of God's grace, Luther and the justification of the unjust, Melanchthon and the origin of Protestant dogmatic, Barth and the sovereignty and trustworthiness of God's election: Would theology have had that without the letter to the Romans? I doubt it. Theology should cherish its Pauline legacy, should learn and teach to study Romans. Thank you Andrie, for studying Romans in our midst and teaching us to focus on its message through its Greek text.

93 Barth, Der Römerbrief (Zweite Fassung), pp. 146-147.

94 Against the meaning of the Greek text of 2 Cor 5:19, the sense of the words i $\lambda$ a $\sigma \kappa \varepsilon \sigma \theta$ a $\kappa \tau \lambda$. and $\kappa \alpha \tau \alpha \lambda \lambda \dot{\alpha} \sigma \sigma \varepsilon เ \nu \kappa \tau \lambda$. and the sources of the metaphors Paul used. See my essays in Breytenbach, Grace.

95 Cf. E. Käsemann, 'Die Heilsbedeutung des Todes Jesu bei Paulus' in Paulinische Perspektiven ( $2^{\text {nd }}$ ed.; Tübingen: Mohr, 1972), pp. 61-107.

96 E. Käsemann, An die Römer (HNT 8,1; Tübingen: Mohr, 1974).

97 Cf. C. Breytenbach, 'Einführung,' in id., Römerbrief, pp. 1-14. 


\section{Bibliography}

\section{Primary sources (editions except PG and PL):}

Abelard, Peter. Commentaria in epistolam Pauli ad Romanos. Vol. 1 of Petri Abaelardi Opera theologica. Edited by Eligius M. Buytaert. CCCM 11. Turnhout: Brepols, 1969.

Aquinas, Thomas. Super epistolas S. Pauli lectura. Vol. 1. Edited by Raphael Cai. $8^{\text {th }}$ rev. ed. Turin: Marietti, 1953.

Augustine. Epistulae ad Romanos inchoata expositio. Sect. 4,1 of Sancti Augustini Opera. Edited by Johannes Divjak. CSEL 84. Vienna: Hoelder-Pichler-Tempsky, 1971.

- Expositio quarundam propositionum ex epistola ad Romanos. Sect. 4,1 of Sancti Augustini opera. Edited by Johannes Divjak. CSEL 84. Vienna: Hoelder-Pichler-Tempsky, 1971.

Calvin, John. Commentarius in epistulam Pauli ad Romanos. Edited by Thomas H. L. Parker. Studies in the History of Christian Thought 22. Leiden: Brill, 1981.

Chrysostom, John. Homiliae in epistolam ad Romanos. Vol. 1 of Sancti patris nostri Ioannis Chrysostomi archiepiscopi Constantinopolitani Interpretatio omnium epistolarum Paulinarum per homilias facta. Edited by Frederick Field. Bibliotheca Patrum Ecclesiae Catholicae. Oxford: J.H. Parker, 1849.

Erasmus. Paraphrases in Novum Testamentum. Vol. 7 of Desiderii Erasmi Roterodami Opera omnia: emendatiora et auctiora ad optimas editiones praecipue quas ipse Erasmus postremo curavit summa fide exacta, doctorumque virorum notis illustrata. Edited by Jean Leclerc. Leiden: P. Vander, 1706; repr., Hildesheim: Olms, 1962.

[Luther, WA] D. Martin Luthers Werke: kritische Gesamtausgabe. 120 vols.

Weimar: Böhlau, 1883ff

Melanchthon, Philipp. Artifitium Epistolae Pauli ad Romanos. Pages 2030 in Texte aus der Anfangszeit Melanchthons. Edited by Ernst Bizer. Texte zur Geschichte der evangelischen Theologie 2. NeukirchenVluyn: Neukirchener Verlag, 1966. 
- Theologica Institutio in Epistolam Pauli ad Romanos. Pages 90-99 in Texte aus der Anfangszeit Melanchthons. Edited by Ernst Bizer. Texte zur Geschichte der evangelischen Theologie 2. Neukirchen-Vluyn: Neukirchener Verlag, 1966.

Rufinus. Der Römerbriefkommentar des Origenes: Kritische Ausgabe der Übersetzung Rufins. Edited by Caroline P. Hammond Bammel. 3 vols. AGLB 16, 33, 34. Freiburg: Herder, 1990-1998.

\section{Works cited:}

Barth, Karl. Der Römerbrief (Erste Fassung) 1919. Edited by Hermann Schmidt. Karl Barthi-Gesamtausgabe 2. Zürich: TVZ, 1985.

- Der Römerbrief (Zweite Fassung) 1922. Edited by Cornelius van der Kooi and Katja Tolstaja. Karl Barth-Gesamtausgabe 2, Zürich: TVZ, 2010.

Baur, Ferdinand Christian. 'Über Zweck und Veranlassung des Römerbriefes und der damit zusammenhängenden Verhältnisse der römischen Gemeinde.' Tübinger Zeitschrift für Theologie (1836): 59-178.

Bingham, D. Jeffrey. 'Irenaeus Reads Romans 8: Resurrection and Renovation.' Pages 114 - 132 in Early Patristic Readings of Romans. Edited by Kathy L. Gaca and Laurence L. Welborn. Romans through History and Cultures Series. New York: T\&T Clark, 2005. Bizer, Ernst. Theologie der Verheißung: Studien zur theologischen Entwicklung des jungen Melanchthon (1519-1524). Neukirchen-Vluyn: Neukirchener Verlag, 1964.

- Introduction to Artifitium Epistolae Pauli ad Romanos a Philippo Melanchthone. Pages 10-19 in Texte aus der Anfangszeit Melanchthons. Edited by Ernst Bizer. Texte zur Geschichte der evangelischen Theologie 2. Neukirchen-Vluyn: Neukirchener Verlag, 1966.

Boguslawski, Steven. 'Thomas Aquinas.' Pages 81-99 in Reading Romans through the Centuries: From the Early Church to Karl Barth. Edited by Jeffrey P. Greenman and Timothy Larsen. Grand Rapids, Mich.: Brazos, 2005.

Bornkamm, Günther. Paulus. Stuttgart: Kohlhammer, 1969. 
- 'Der Römerbrief als Testament des Paulus.' Pages 120-139 in Geschichte und Glaube: Zweiter Teil. Vol. 4 of Gesammelte Aufsätze. BEvT 53. München: Kaiser, 1971.

Breytenbach, Cilliers. Grace, Reconciliation, Concord: The Death of Christ in Graeco-Roman Metaphors. NovTSup 135. Leiden: Brill, 2010.

- 'Einführung.' Pages 1-14 in Der Römerbrief als Vermächtnis an die Kirche: Rezeptionsgeschichten aus zwei Jahrtausenden. Edited by Cilliers Breytenbach. Neukirchen-Vluyn: Neukirchener Verlag, 2012. Breytenbach, Cilliers, ed. Der Römerbrief als Vermächtnis an die Kirche: Rezeptionsgeschichten aus zwei Jahrtausenden. Neukirchen-Vluyn: Neukirchener Verlag, 2012.

Bright, Pamela. 'Augustine.' Pages 59-80 in Reading Romans through the Centuries: From the Early Church to Karl Barth. Edited by Jeffrey P. Greenman and Timothy Larsen. Grand Rapids, Mich.: Brazos, 2005.

Brown, Michael J. 'Jewish Salvation in Romans according to Clement of Alexandria in Stromateis 2.' Pages 42-62 in Early Patristic Readings of Romans. Edited by Kathy L. Gaca and Laurence L. Welborn. Romans through History and Cultures Series. New York: T\&T Clark, 2005.

Classen, Carl J. 'Paulus und die antike Rhetorik.' ZNW 82 (1991): pp. 1-33.

Clements, Ruth. 'Origen's Reading of Romans in Peri Archon: (Re) Constructing Paul.' Pages 159-179 in Early Patristic Readings of Romans. Edited by Kathy L. Gaca and Laurence L. Welborn. Romans through History and Cultures Series. New York: T\&T Clark, 2005.

Domanyi, Thomas. Der Römerbriefkommentar des Thomas von Aquin: Ein Beitrag zur Untersuchung seiner Auslegungsmethoden. Basler und Berner Studien zur historischen und systematischen Theologie 39. Basel: Peter Lang, 1979.

Donfried, Karl P., ed. The Romans Debate. Rev. and expanded ed. Peabody, Mass.: Hendrickson, 1991.

Drecoll, Volker Henning. Die Entstehung der Gnadenlehre Augustins.

BHT 109. Tübingen: Mohr Siebeck, 1999. 
Du Toit, Andrie B. Focusing on Paul: Persuasion and Theological Design in Romans and Galatians. Edited by Cilliers Breytenbach and David S. du Toit. BZNW 151. Berlin: de Gruyter, 2007.

Fliethmann, Thomas. 'Augustinische Akzente in der Gotteslehre des Thomas von Aquin (1224/5-1274).' Pages 127-139 in Von den Anfängen bis zur Reformation. Vol. 1 of Augustinus: Spuren und Spiegelungen seines Denkens. Edited by Norbert Fischer. Hamburg: Meiner, 2009.

Gese, Michael. Das Vermächtnis des Apostels: Die Rezeption der paulinischen Theologie im Epheserbrief. WUNT 2/99. Tübingen: Mohr Siebeck, 1997.

Graham, Susan L. 'Irenaeus as Reader of Romans 9-11: Olive Branches.' Pages 87-113 in Early Patristic Readings of Romans. Edited by Kathy L. Gaca and Laurence L. Welborn. Romans through History and Cultures Series. New York: T\&T Clark, 2005.

Greenman, Jeffrey P., and Larsen, Timothy, eds. Reading Romans through the Centuries: From the Early Church to Karl Barth. Grand Rapids, Mich.: Brazos, 2005.

Hall, Christopher A. 'John Chrysostom.' Pages 39-57 in Reading Romans through the Centuries: From the Early Church to Karl Barth. Edited by Jeffrey P. Greenman and Timothy Larsen. Grand Rapids, Mich.: Brazos, 2005.

Hammond Bammel, Caroline P. Der Römerbrieftext des Rufin und seine Origenes-Übersetzung. AGLB 10. Freiburg: Herder, 1985.

Heither, Theresia. Introduction to Origenes, Commentarii in epistulam ad Romanos/ Römerbriefkommentar. Fontes Christiani 2,1. Freiburg: Herder, 1990.

Käsemann, Ernst. An die Römer. HNT 8,1. Tübingen: Mohr, 1974.

- 'Die Heilsbedeutung des Todes Jesu bei Paulus.' Pages 61-107 in Paulinische Perspektiven. $2^{\text {nd }}$ ed. Tübingen: Mohr, 1972. 
Karfíková, Lenka. 'Zur Rezeption Augustins bei Peter Abaelard (ca. 1079-1142).' Pages 71-83 in Von den Anfängen bis zur Reformation. Vol. 1 of Augustinus: Spuren und Spiegelungen seines Denkens. Edited by Norbert Fischer. Hamburg: Meiner, 2009.

[Landes] Augustine on Romans: Propositions from the Epistle to the Romans. Unfinished Commentary on the Epistle to the Romans. Translated by Paula F. Landes. SBLTT 23. Chico, Calif.: Scholars Press, 1982.

Lindemann, Andreas. Paulus im ältesten Christentum: Das Bild des Apostels und die Rezeption der paulinischen Theologie in der frühchristlichen Literatur bis Marcion. BHT 58. Tübingen: Mohr, 1979.

Lohmann, Friedrich. 'Die Krisis des Glaubens: Karl Barths Auslegung des Römerbriefes.' Pages 135-160 in Der Römerbrief als Vermächtnis an die Kirche: Rezeptionsgeschichten aus zwei Jahrtausenden. Edited by Cilliers Breytenbach. Neukirchen-Vluyn: Neukirchener Verlag, 2012.

Miller, James C. 'The Romans Debate 1991-2001.' CurBS 9 (2001): pp. 306-349.

[Owen] John Calvin, Commentaries on the Epistle of Paul the Apostle to the Romans. Translated and edited by John Owen. Edinburgh: Calvin Translation Society, 1849.

[Payne] Erasmus, New Testament Scholarship: Paraphrases on Romans. Translated and annotated by John B. Payne, Albert Rabil Jr., and Warren S. Smith Jr. Vol. 42 of Collected Works of Erasmus. Edited by Robert D. Sider. Toronto: University of Toronto Press, 1984.

Peppermüller, Rolf. Introduction to Petri Abaelardi Expositio in epistolam ad Romanos/ Römerbriefkommentar. Fontes Christiani 26,1. Freiburg: Herder, 2000.

[Preus] Martin Luther, Lectures on Romans: Glosses and Scholia.

Translated by Walter G. Tillmanns (ch. 1-2) and Jacob A. O. Preus (ch. 3ff.). Vol. 25 of Luther's Works. Edited by Hilton C. Oswald; St. Louis, Miss.: Concordia, 1972. 
Ring, Thomas Gerhard. 'Expositio quarundam propositionum ex epistula apostoli ad Romanos.' Columns 1209-1218 in vol. 2 of AugustinusLexikon. Edited by Cornelius Mayer et al. Basel: Schwabe, 2002.

[Scheck] Origen, Commentary on the Epistle to the Romans: Book 1-5. Translated from Rufinus' Latin translation of the Original Greek by Thomas P. Scheck. FC 103. Washington, D.C.: CUA Press, 2001.

Scherer, Jean. Le commentaire d'Origène sur Romans. III.5NV.7: D'après les Extraits du Papyrus No 88748 du Musée du Caire et les Fragments de la Philocalie et du Vaticanus Gr. 762. Cairo: L'Institut Français d'Archéologie Orientale, 1957.

Shepherd, Victor. 'John Wesley.' Pages 149-168 in Reading Romans through the Centuries: From the Early Church to Karl Barth. Edited by Jeffrey P. Greenman and Timothy Larsen. Grand Rapids, Mich.: Brazos, 2005.

Souter, Alexander. The Earliest Latin Commentaries on the Epistles of St. Paul: A Study. Oxford: Clarendon, 1927.

Staab, Karl, ed. Pauluskommentare aus der griechischen Kirche. NTAbh 15. Münster: Aschendorff, 1933.

[Thornton] Martin Luther, Preface to the Letter of St. Paul to the Romans. Translated by Andrew Thornton. No pages. [Online] Available: http:// www.ccel.org///luther/romans/pref_romans.html [Accessed 14 March 2012].

Welborn, Laurence L. 'The Soteriology of Romans in Clement of Alexandria, Stromateis 2: Faith, Fear, and Assimilation to God.' Pages 66-83 in Early Patristic Readings of Romans. Edited by Kathy L. Gaca and Laurence L. Welborn. Romans through History and Cultures Series. New York: T\&T Clark, 2005.

Wendebourg, Dorothea. 'Der Römerbrief bei Martin Luther.' Pages 119-134 in Der Römerbrief als Vermächtnis an die Kirche: Rezeptionsgeschichten aus zwei Jahrtausenden. Edited by Cilliers Breytenbach. Neukirchen-Vluyn: Neukirchener Verlag, 2012. 
Wischmeyer, Wolfgang. 'Die Rezeption des Paulus in der Geschichte der Kirche.' Pages 358-368 in Paulus: Leben - Umwelt - Werk - Briefe. Edited by Oda Wischmeyer. Tübingen: Francke, 2006. 